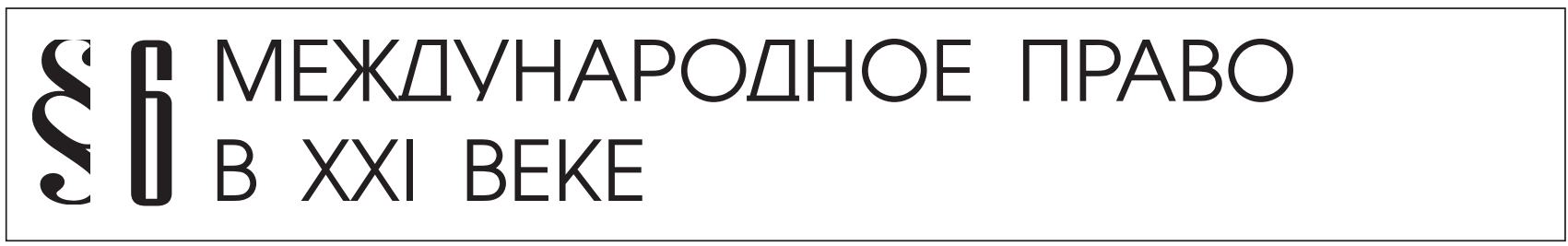

Жудро И.С.

\title{
СЕКТОРАЛЬНЫЙ МЕТОД КАК СПОСОБ СПРАВЕДЛИВОГО РАЗГРАНИЧЕНИЯ ДНА СЕВЕРНОГО ЛЕДОВИТОГО ОКЕАНА
}

\begin{abstract}
Аннотация: Предмет исследования-международно-правовой режим дна Северного Ледовитого океана с акиентом на значение обычаев в решении актуальных вопросов его разграничения. Исследована практика Международного Суда ООН в решении спорных вопросов разграничения континентального шельфа. а также использование секторального метода (метода меридианных линий) при разграничении полярных пространств в Русско-английской конвенции 1825 года, в Конвенции об уступке Аляски 1867 года, в Соглатении между СССР и США о линии разграничения морских пространств 1990 года, а также в Соглашении 2011 года о разграничении государствами Арктического совета авиационных и морских поисково-спасательных районов. Предпринят сравнительный анализ существующих правовых механизмов определения грании континентального шельфа: «делимитации» и её методов, которые приобрели силу обычаев, а также основанного на статье 76 Конвенщии ООН по морскому праву 1982 года «отграничения» шельфа в пользу Международного района морского дна. Впервые дана критическая оиенка современной международно-правовой позиции Российской Федерации в отношении грании континентального шельфа в Северном Ледовитом океане. Сделан вывод о том, что существующий международно-правовой режим дна Северного Ледовитого океана, включая обычай секторального деления полярных пространств, позволит России достичь справедливого результата при разграничении арктического шельфа с соседними государствами без обращения в Комиссию по гранииам континентального шельфа, на основании соглашений о делимитации, избежав споров, неоправданных пространственных уступок и обеспечив национальные интересы.
\end{abstract}

Ключевые слова: Международно-правовой режим, Северный Ледовитый океан, международные обычаи, Международный Суд ООН, континентальный шельф, делимитация континентального шельфа, отграничение континентального шельфа, метод меридианных линий, Комиссия гранииам шельфа, Район морского дна.

Abstract: The subject of this research is the international legal regime of the seabed of the Arctic Ocean with accent on the significance of the customs in resolving pressing issues of its delimitation. The author examines the precedent of the International Court of Justice on resolution of disputes in demarcation of the continental shelf, as well as the use of the sectoral method (method of meridian lines) in demarcation of the polar territories in the Anglo-Russian Convention of 1825, Alaska Purchase (1867), USSR-USA Maritime Boundary Agreement (1990), and the 2011 agreement on delineation of the aviation and maritime search and rescue regions by the countries of the Arctic Council. The conclusion is made that the current international legal regime of the seabed of the Arctic Ocean, including the custom of sectoral division of the polar territories, would allow Russia to achieve an equitable result in delimitation of the Arctic shelf with the neighboring countries without turning to the Commission on the Limits of the Continental Shelf, based on the treaties on delimitation, avoiding disputes, unjustified territorial concessions, and ensure national interests.

Keywords: Method of meridian lines, delineation of the Continental Shelf, delimitation of the Continental Shelf, Continental Shelf, International Court of Justice, international customs, Arctic Ocean, international legal regime, Commission on the Limits of the Continental Shelf, International Seabed Area. 


\section{Право и политика $6(186) \cdot 2015$}

$\Pi$

равовой режим Северного Ледовитого океана (далее также - СЛО) достаточен для «мирного разрешения споров, вытекающих из любых возможных претензий», - было объявлено прибрежными арктическими государствами (Россия, Канада, Дания, Норвегия, США) в принятой ими в 2008 году Илулиссатской декларации [1].

Подобная констатация тем более важна и актуальна, что сегодня между Россией и соседними с ней прибрежными странами - Канадой, Данией и США не разграничен арктический шельф, богатый природными ресурсами.

Нормы международного права определяют континентальный шельф прибрежного государства как морское дно и недра подводных районов, простирающихся за пределы его территориального моря на всем протяжении естественного продолжения его сухопутной территории. Границы шельфа между государствами с противолежащими или смежными побережьями устанавливаются путем заключения соглашения о делимитации (delimitation), как указывается в статье 38 Статута Международного Суда ООН, в целях достижения справедливого решения.

Международный Суд ООН допускает возможность «прибегать к различным принципам и методам делимитации, насколько это может быть уместным, или к сочетанию таких принципов и методов при условии, что применением принципов справедливости достигается разумный результат» (дело о континентальном шельфе Северного моря (между ФРГ и Данией; между ФРГ и Нидерландами) решение от 20 февраля 1969 г.). [2, с. 105] Речь, в частности, может идти о методах равного отстояния, срединной линии и меридианных линий (секторальном).

Метод меридианных линий, сходящихся в точке Северного полюса, впервые был применен при разграничении «полярных владений» в Русскоанглийской конвенции 1825 года и в Русскоамериканской конвенции об уступке Аляски 1867 года (см. схему № 1). [3, с. 77] Тогда эти линии, естественно, не предназначались для континентального шельфа - такой институт не был известен международному праву XIX и начала XX веков.

Метод меридианных линий нашел свое применение в национальном законодательстве арктических стран. В 1925 году Канада в границах своего арктического «сектора» регламентировала разведку и разработку природных ресурсов (the Northwest Territories Act), а в 1926 году - установила режим природопользования на арктических островах (the Arctic Islands Preserve). [4, с. 242]

В 1926 году территорией Союза ССР были объявлены «все как открытые, так и могущие быть открытыми в дальнейшем земли и острова, не составляющие ... территории каких-либо иностранных государств, расположенные в Северном Ледовитом океане, к северу от побережья Союза ССР до Северного полюса»в пределах между меридианами, проходящими через восточную и западные оконечности территории страны. [4, с. 242]

Арктический «сектор» получил свое закрепление и на уровне доктрины международного права. Такое преимущество секторального принципа при разграничении пространств в Арктике как простота отмечалось как отечественными [5], так и зарубежными [6] правоведами (см. схему № 2). $[3$, c. 78$]$

На сегодня можно говорить о сформированном вековой практикой международном обычае разграничивать полярные пространства по меридианным линиям. В заключенном в 1990 году СССР и США Соглашении о разграничении морских пространств в Северном Ледовитом океане использовалась меридианная линия Конвенции 1867 года. Современное международное право не запрещает использовать ранее согласованные межгосударственные границы для новых целей, при наличии совпадающего волеизъявления заинтересованных государств.

Свежим свидетельством применимости секторального метода в полярных регионах (напрямую не связанным с делимитацией морских пространств) стало разграничение арктическими государствами авиационных и морских поисково-спасательных районов в Соглашении о сотрудничестве в авиационном и морском поиске и спасании в Арктике (заключено в г. Нууке 12 мая 2011 г.) (см. схему № 3). [7, с. 21-32]

Наряду с общепризнанными принципами и методами разграничения (делимитации) морских пространств, которые приобрели силу международных обычаев, Конвенцией 1982 года был внедрен новый правовой институт - «международный район морского дна» (далее также - Район).

В пользу такого Района, недра которого объявлены «общим наследием человечества», каждое 
прибрежное государство должно «отграничить» свой континентальный шельф на расстоянии в 200 морских миль от исходных линий или за пределами 200 морских миль - по внешней границе подводной окраины материка, определяемой на основании рекомендаций специального технического органа - Комиссии по границам континентального шельфа (г. Нью-Йорк) (далее также - Комиссия). Нормы Конвенции, которые предусмотрели «отграничение» (delineation) континентального шельфа прибрежного государства в пользу Района - силу международного обычая не приобрели и поэтому не стали обязательными для государств, не присоединившихся к Конвенции (например, для США).

Спорным является вопрос применимости института «международный район морского дна» («общее наследие человечества») к подводным пространствам Северного Ледовитого океана. Целесообразность создания Района в центре СЛО (скованного вековыми льдами, самого малого и мелководного из океанов, полузамкнутого побережьями пяти государств) до настоящего времени не является очевидной. [8, с. 19-24]

Неслучайно, по сведениям российских источников, СССР в числе других заинтересованных государств, в ходе III Конференции ООН по морскому праву отводил попытки включить полярные регионы в предмет регулирования Конвенцией ООН по морскому праву. [4, с. 29]

Сегодня уже очевидно, что намерение посредством Комиссии осуществить «отграничение» участков дна СЛО в пользу Района провоцирует спорную ситуацию. В силу труднодоступности для изучения геологического строения дна СЛО попытки одного государства обосновывать собственную концепцию «отграничения» шельфа в пользу Района будут неизбежно сводиться к построению научных предположений (о природе происхождения элементов морского дна) и, весьма вероятно, вызовут возражения соседних государств. С учетом оспоримости всяких предположений такие пространственные притязания не смогут найти в Комиссии свое окончательное разрешение (см.: Приложение II к Конвенции ООН по морскому праву 1982 г. «Комиссия по границам континентального шельфа»). [9, с. 3 -168]

Правила процедуры Комиссии не допускают вынесения на её рассмотрение неурегулированных территориальных либо морских споров. При наличии спора Комиссия не рассматривает и не оценивает представление, сделанное каким-либо из государств, затрагиваемых спором.

Комиссия может рассмотреть одно или несколько представлений по спорному району с предварительного согласия всех государств, являющихся сторонами в таком споре. Комиссия определяет пределы своей компетенции границами «бесспорного» шельфа, не затрагивая вопросы, касающиеся его делимитации (п. 4 Приложения I к Правилам Процедуры). Таким образом, возможность «отграничения» шельфа от Района обусловлено отсутствием всякого территориального или морского спора. В распоряжении Комиссии, выносящей рекомендации по «отграничению», - только геологические и геоморфологические критерии статьи 76 Конвенции 1982 года. Причем Комиссия не имеет возможности учитывать такие аспекты как природоохранные и военные, непосредственно затрагивающие интересы соседних прибрежных государств. [10, с. 7 - 13]

Тем не менее в 2001 году Россия первой из арктических прибрежных государств обратилась в Комиссию с представлением об «отграничении» своего арктического шельфа от Района, в качестве которого был квалифицирован участок дна площадью более 300 тысяч кв. км., на который до этого ни одно государство не претендовало и который на уровне правосознания и доктринальных квалификаций рассматривался prima facie как находящийся под юрисдикцией России (поскольку находился внутри российского полярного «сектора») (см. схему № 4). [11]

В результате - формировавшийся на протяжении веков правовой режим Арктики был подвергнут достаточно серьезному пересмотру. Использование геологических критериев статьи 76 Конвенции 1982 года для установления границ в арктическом регионе в одночасье изменило международно-правовую доктрину в отношении высокоширотных пространств.

На момент российской инициативы - обращение в 2001 г. в Комиссию Канада и Дания не участвовали в Конвенции, Норвегия - не обращалась в Комиссию, США - до сих пор воздерживаются от участия в Конвенции. Советская правовая доктрина всегда исходила из правовой уникальности СЛО. Обобщая ее, профессор В. Н. Кулебякин пишет: «Именно комплекс исторических, экономических, политических, геологических и 


\section{Право и политика 6 (186) • 2015}

других факторов позволяет сделать вывод, что арктические морские пространства не могут рассматриваться под тем же углом зрения, что и морские пространства вообще». [12, с. 139]

Российское обращение в Комиссию в 2001 году не имело успеха (сочтя представление неубедительным, Комиссия отказала в положительных рекомендациях), но подтолкнуло Канаду и Данию к присоединению к Конвенции 1982 г. и к подготовке собственных представлений по статье 76, носящих потенциально конкурентный характер по отношению к российской позиции. (С Канадой раньше такой конкуренции не было, в силу следования Канады и Советского Союза секторальному размежеванию властных, прежде всего, природоохранных, полномочий в Арктике).

В декабре 2014 года о встречных притязаниях на арктический шельф заявила Дания. [13] Выйдя за пределы собственного полярного «сектора», Копенгаген отнес к своему шельфу не только Северный полюс, но и значительную часть полярного «сектора» России, включая участок дна, уступленный в пользу Района, - вплоть до 200 -мильных границ российской исключительной экономической зоны. [14]

В результате - российский полярный «сектор» в районе хребта Ломоносова стал объектом датских притязаний. Создалась спорная ситуация, которую может обострить вмешательство Канады, объявившей в 2013 году о намерении заявить претензии на дно центральной части СЛО.

Таким образом, используя одни и те же геологические критерии статьи 76 Конвенции, Россия и Дания претендуют на один и тот же участок морского дна - хребет Ломоносова. Сопоставление этих претензий наглядно демонстрирует неодинаковую степень «эффективности» использования одной и той же нормы: если Россия поступилась значительной частью собственного полярного «сектора», то Дания вышла за пределы своего «сектора», существенно затронув интересы России.

При этом Дания и Россия не воспользовались правом взаимно согласовать геодезические пределы встречных представлений без ущерба для последующей делимитации (п. 4 Приложения I к Правилам процедуры Комиссии). Вместо этого ими была заключена договоренность, по которой стороны отказались от возражений в отношении представлений друг друга и возможности выне- сения по ним рекомендаций Комиссии, что, с учетом очевидного «неравенства» пространственных притязаний, выгодней Дании, чем России. [14] Договоренность создала условия для беспрепятственного рассмотрения Комиссией датских притязаний и вынесения по ним положительных рекомендаций и, как следствие, признания установленных на их основе границ датского шельфа окончательными и обязательными для всех.

В этой связи особого внимания заслуживает аргументация необходимости обращения в Комиссию для разграничения арктического шельфа России и Дании - «сначала Комиссия по границам континентального шельфа должна подтвердить, что участки дна, на которые претендуют Россия и Дания, являются собственно континентальным шельфом». И лишь затем «возможные соприкасающиеся участки шельфа наших стран в высокоширотной Арктике будут разграничены в двустороннем порядке, путем переговоров, на основе международного права». [13]

Между тем, ни Конвенция 1982 года, ни Правила Процедуры не наделяют Комиссию правовыми полномочиями устанавливать юридический факт отнесения или неотнесения участка дна к континентальному шельфу прибрежного государства. Являясь техническим органом, Комиссия дает прибрежному государству рекомендации по отграничению его шельфа от Района.

Кроме того, международному морскому праву известен институт «континентальный шельф прибрежного государства», а не «собственно континентальный шельф». Международный Суд ООН исходит из того, что континентальный шельф составляет естественное продолжение сухопутной территории конкретного прибрежного государства и его права на шельф существуют ipso facto и ab initio (в силу факта и изначально), вследствие его суверенитета над этой территорией» (дело о континентальном шельфе Северного моря (между ФРГ и Данией; между ФРГ и Нидерландами) решение от 20 февраля 1969 г.). [2, с. 95]

Безотносительно к определенному прибрежному государству понятие «континентальный шельф»не существует и рассматриваться не может, а предположение о том, что Комиссия правомочна давать заключение об отнесении спорного участка морского дна к «собственно континентальному шельфу» - не основано на нормах международного права. 
Между тем возможность разграничить арктический шельф на справедливых условиях, не прибегая к Комиссии, - сохраняется. Дания в своем представлении 2014 года указала, что окончательная делимитация шельфа к серверу от Гренландии будет надлежаще осуществлена в соответствии с двусторонними договоренностями, предусмотренными статьей 83 Конвенции 1982 года. Тем самым Дания повторила свою прежнюю позицию (нота от 4 февраля 2002 г.) когда, не согласившись с российским представлением 2001 года, указала на то, что «действия Комиссии не должны наносить ущерба в вопросах, относящихся к делимитации шельфа между государствами, имеющими противолежащие или смежные побережья». [11] Аналогичная позиция высказана и в ноте Канады от 18 января 2002 г. [11]

Согласно выводам Международного суда $\mathrm{OOH}$, в случаях, когда делимитация на море необходима, прибрежные государства «обязаны вести переговоры с целью достигнуть соглашения, причем делать это добросовестно, с подлинным намерением достигнуть позитивного результата» (дело о делимитации морской границы в заливе Мэн (между Канадой и США). Решение от 12 октября 1984 г.). [2, с. 100] Россия, Канада, Дания, как участники Конвенции 1982 г., вправе разграничить арктический шельф, руководствуясь ст. 83 этой Конвенции.

При этом значительная часть границ арктического шельфа может получить свое окончательное оформление уже сегодня на основе взаимных договоренностей сторон, без необходимости обращения в Комиссию. [15, с. 41] Для этого, согласно мнению отечественных экспертов, все дно СЛО, в совпадающих интересах арктических государств, берега которых его замыкают, следует квалифицировать как континентальный шельф этих государств, подлежащий делимитации между ними в соответствии с международным правом (безотносительно к критериям статьи 76 Конвенции 1982 года). Основания для такой квалификации - в уникальных географических и природных особенностях СЛО, в его исторически сложившемся правовом режиме, базирующемся на международных обычаях - многовековом осуществлении арктическими странами своей юрисдикции в полярных «секторах». [16, с. 147-151]

Без обращения в Комиссию, например, были разграничены морские пространства в Баренцевом море и в Северном Ледовитом океане по Договору между Российской Федерацией и Королевством Норвегия от 15 сентября 2010 г. [17, с. 79-85] Россия и Норвегия разграничили арктический шельф на участках морского дна за пределами 200-мильных исключительных экономических зон в замкнутом ими так называемом «анклаве» Баренцева моря.

По Соглашению между СССР и США о линии разграничения морских пространств от 1 июня 1990 г. стороны разделили районы континентального шельфа в морях СЛО, в том числе за 200 -мильным расстоянием от исходных линий, вне правового режима Конвенции 1982 г. [18, c. 33-37] Меридианная линия по Соглашению 1990 г. вполне может стать «основой для разграничения арктического шельфа между Россией и США... при том понимании, что эта линия простирается до Северного географического полюса...».[19] Неучастие США в Конвенции 1982 года не будет препятствовать делимитации шельфа, которая может быть осуществлена в ином правовом режиме. Во взаимоотношениях с США не действует положение Конвенции 1982 г. о преимуществе ее норм над нормами Женевских морских конвенций 1958 г. (ч. 1 ст. 311 Конвенции 1982 г.). Следовательно, разграничить свой шельф с США Россия и Канада могут, руководствуясь положениями Конвенции 1958 года.

Таким образом, существующий международно-правовой режим Северного Ледовитого океана, включая обычаи секторального деления полярных пространств, позволит России достичь справедливого результата при разграничении арктического шельфа с соседними государствами - на основании соглашений о делимитации, без обращения в Комиссию по границам континентального шельфа, избежав споров, неоправданных пространственных уступок и обеспечив национальные интересы.

Представленные выводы могут быть учтены в работе ответственных федеральных органов исполнительной власти по реализации утвержденной Президентом Российской Федерации Стратегии развития Арктической зоны Российской Федерации и обеспечения национальной безопасности на период до 2020 года (п. 29, пп. «г»), в которой поставлена задача - не допустить пространственных уступок и создания конкурентных преимуществ другим государствам при определении внешних границ континентального шельфа. [20] 
DOI: $10.7256 / 1811-9018.2015 .6 .15168$

При цитировании этой статьи сноска на dоі обязательна

\section{Право и политика $6(186) \cdot 2015$}

Схема № 1

Секторальные линии в Арктике

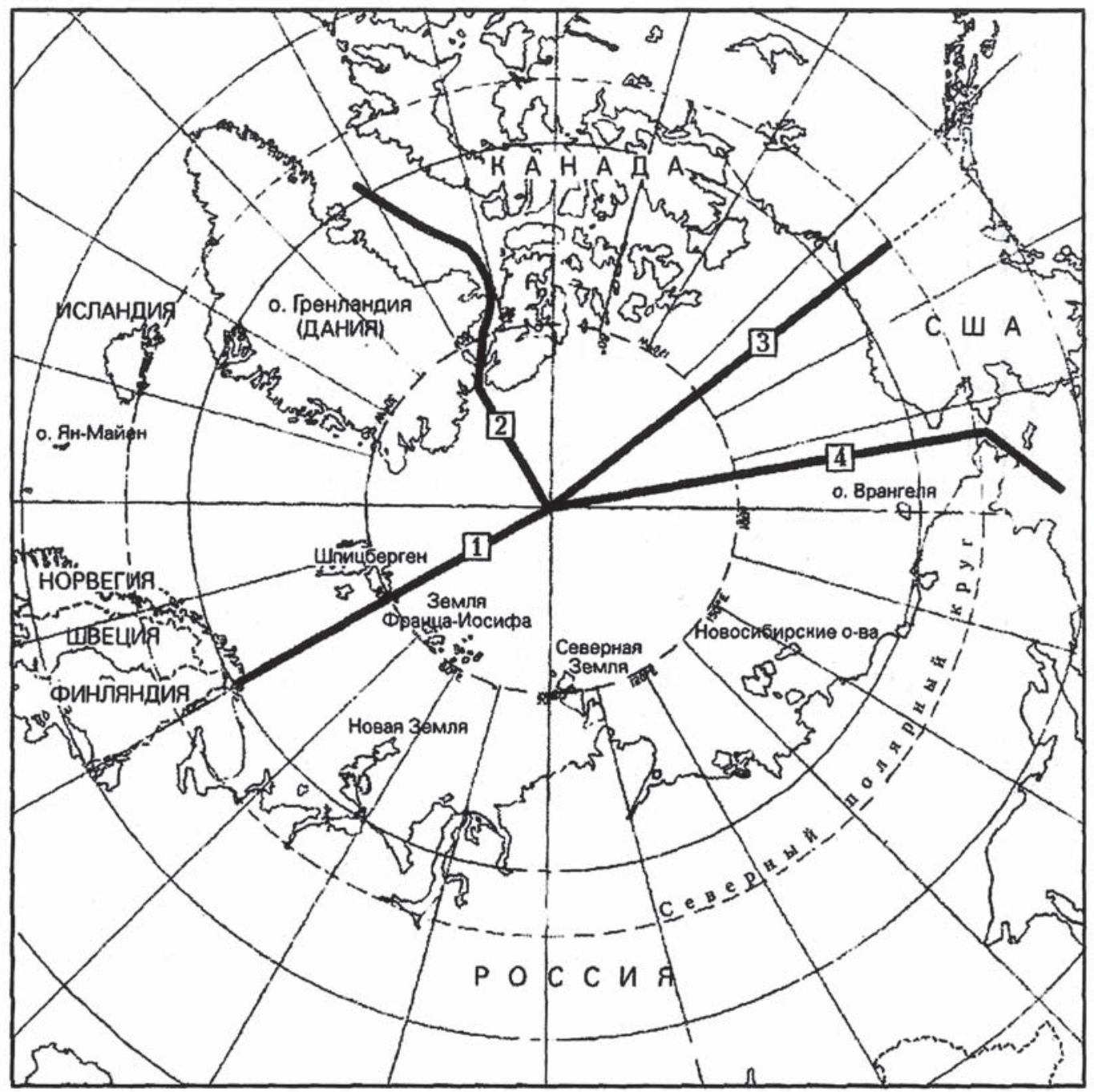

1 - Постановление Президиума ЦИК СССР от 15 апреля 1926 г. «Об объявлении территорией Союза ССР земель и островов, расположенных в Северном Ледовитом океане»

Decree of the Presidium of the USSR Central Executive Committee of 1926 "On Declaration of Lands and Islands situated in the Artic Ocean as the USSR Territory";

2 - законы Канады о Северо-Западных территориях 1907 г., 1925 г.

The Northwest Territories Act of Canada 1907, 1925;

3 - Русско-английская конвенция о границах 1825 г.

Anglo-Russian Boundary Convention of 1825;

4 - Договор об уступке Российских владений в Северной Америке... 1867 г. («Конвенция об уступке Аляски» 1867 г.)

Treaty concerning the Cession of the Russian Possessions in North America... of 1867 ("Convention concerning the Cession of Alaska" of 1867). 
DOI: $10.7256 / 1811-9018.2015 .6 .15168$

При цитировании этой статьи сноска на dоі обязательна

Международное право в XXI веке

Схема № 2

Доктринальное обозначение пяти арктических секторов

(иностр.доктрина: GUSTAV SMEDAL)

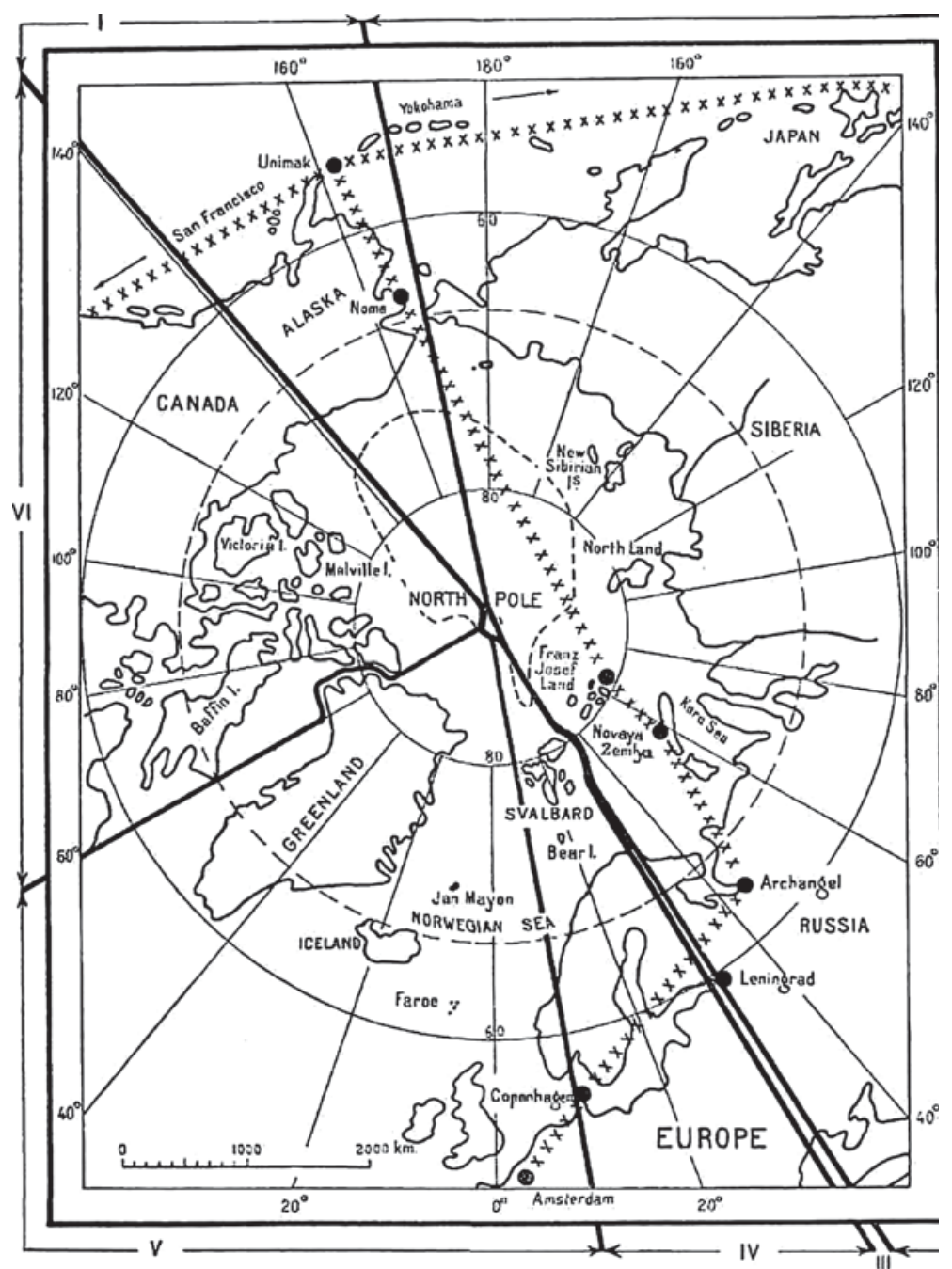

THE NORTH POLAR REGION

ссылка на публикацию НКИД СССР (проф. Лахтина В.Л.) - «Sector division as proposed by V. L. Lakhtine»

I United States' Sector IV Norwegian Sector

II Soviet Union' Sector V Danish Sector

III Finnish Sector VI Canadian Sector 
DOI: $10.7256 / 1811-9018.2015 .6 .15168$

При цитировании этой статьи сноска на dоі обязательна

\section{Право и политика $6(186) \cdot 2015$}

Схема № 3

Использование секторального подхода при разграничении между пятью арктическими прибрежными государствами районов ответственности по Соглашению о сотрудничестве в авиачионном и морском поиске и спасании в Арктике, 2011 г.

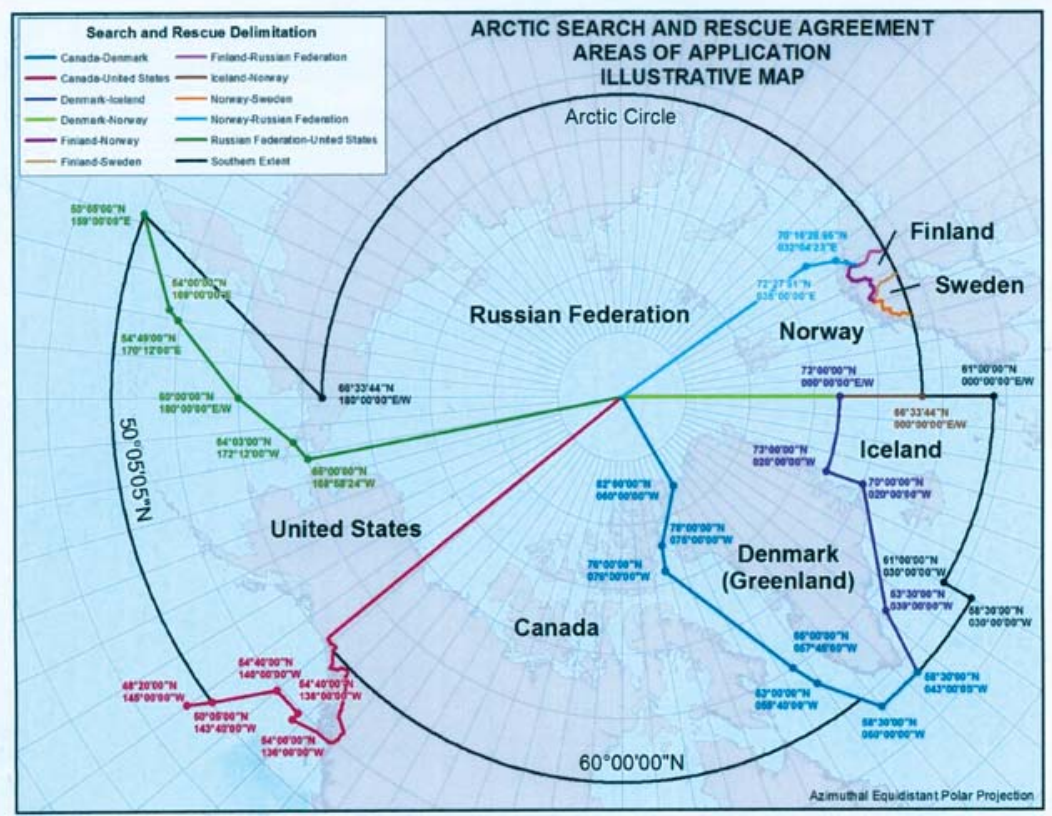

Схема № 4

Данные, представленные Россией в Комиссию по границам континентального шельфа 20 декабря 2001 г.: буквой «А» обозначен Район «общего наследия человечества».

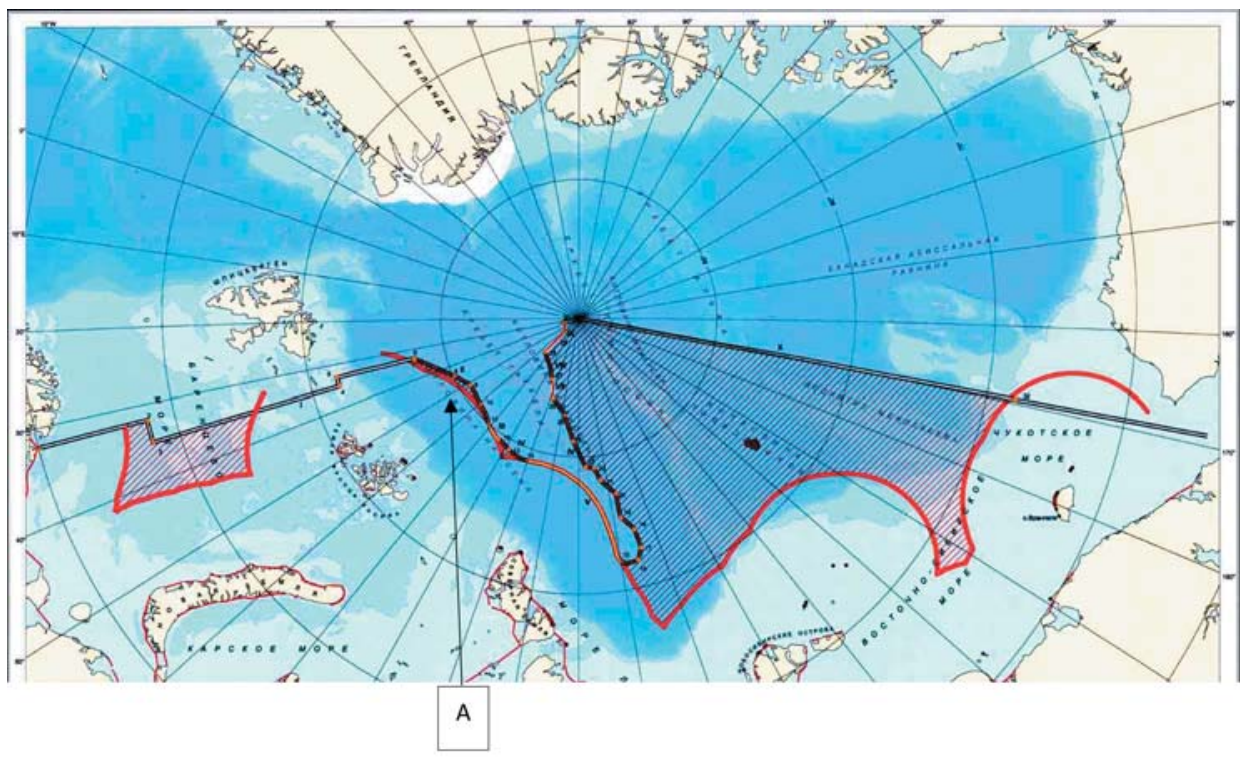

Адаптировано из Источника: официальный Интернет-сайт ООН. Доступ к ресурсу: http://www.un.org/Depts/los/clcs_new/submissions_files/rus01/RUS_CLCS_01_2001_LOS_2.jpg 


\section{Библиография:}

1. ILulissat Declaration, Arctic Ocean Conference, Greenland, 27-29 May 2008. URL: http://arctic-concil.org/filearchive/llulissatdeclaration.pdf (16 June 2009).

2. Вылегжанин А.Н. Решения Международного Суда ООН по спорам о разграничении морских пространств. Юридическая литература, 2004.

3. Николаев А. Н., Пещуров И. С. Правовые возможности предотвращения потери Россией высокоширотного участка арктического шельфа. Современные производительные силы. - М.: СОПС. - № 1/2014.

4. Правовое положение Арктического региона в документах // Арктический регион. Христоматия в 3 томах. - Т. 3. Применимые правовые источники / Гл. ред. И. С. Иванов. - М., 2013.

5. Лахтин В. Л. Права на северные полярные пространства. Издание Литиздата Народного Комиссариата по иностранным делам. - М., 1928, 48 с.

6. Smedal G. Op. cit. P. 12.

7. Бюллетень международных договоров. - 2013. - № 9.

8. Жудро И.С. Сравнительный анализ актуальных подходов к решению проблемы международного закрепления границ континентального шельфа России в Арктике//Евразийский юридический журнал. - 2015.-№ 1(80).

9. Бюллетень международных договоров. - 1998. - № 1.

10. Жудро И.С. Международно-правовой режим Северного Ледовитого океана в условиях глобализации. Вероятные риски и угрозы национальной безопасности Российской Федерации в Арктике // Армия и общество. - 2015.-№ 1.

11. Официальный Интернет-сайт ООН. Доступ к ресурсу: http://www.un.org/Depts/los/clcs_new/submissions files/rus.

12. Кулебякин В. Н. Правовой режим Арктики. Международное морское право / Отв. ред. И. П. Блищенко. - М., 1988.

13. Официальный сайт МИД России: Комментарий Департамента информации и печати МИД России в связи с подачей Данией заявки на континентальный шельф в Арктике http://mid.ru 2888-16-12-2014.

14. Partial Submission of the Government of the Kingdom of Denmark together with the Government of Greenland to the Commission on the Limits of the Continental Shelf (The Northern Continental Shelf of Greenland):http://um.dk/en/ /media/UM/Danish-site/ Documents/Udenrigspolitik/Nyheder_udenrigspoliti... (08/04/2015).

15. Вылегжанин А. Н. Уточнение пределов юрисдикции России в Арктике на основе общего международного права // Международные суды: актуальные проблемы международного права / межвузовский сборник научных трудов. - Вып. № 2(6). - Екатеринбург, 2010.

16. Пещуров И. С. Режим дна Северного Ледовитого океана согласно международному обычному праву // Московский журнал международного права. - 2014. - № 3(95) июль-сентябрь.

17. Бюллетень международных договоров. - 2011. - № 12.

18. Бюллетень международных договоров. - 2008. - № 1 .

19. Вылегжанин А. Н. 20 лет «временного применения» Соглашения между СССР и США о линии разграничения морских пространств // Вестник МГИМО-Университета. - 2010. - № 1.

20. Стратегия развития Арктической зоны Российской Федерации и обеспечения национальной безопасности на период до 2020 года (утв. Президентом Российской Федерации 8 февраля 2013 г. Пр-232). Доступ к ресурсу: http://www.government.ru (20/02/2013).

\section{References (transliterated):}

1. Vylegzhanin A.N. Resheniya Mezhdunarodnogo Suda OON po sporam o razgranichenii morskikh prostranstv. Yuridicheskaya literatura, 2004.

2. Nikolaev A. N., Peshchurov I. S. Pravovye vozmozhnosti predotvrashcheniya poteri Rossiei vysokoshirotnogo uchastka arkticheskogo shel'fa. Sovremennye proizvoditel'nye sily. - M.: SOPS. - № 1/2014.

3. Lakhtin V. L. Prava na severnye polyarnye prostranstva. Izdanie Litizdata Narodnogo Komissariata po inostrannym delam. - M., $1928,48 \mathrm{~s}$.

4. Smedal G. Op. cit. P. 12.

5. Zhudro I.S. Sravnitel'nyi analiz aktual'nykh podkhodov k resheniyu problemy mezhdunarodnogo zakrepleniya granits kontinental'nogo shel'fa Rossii v Arktike//Evraziiskii yuridicheskii zhurnal. - 2015.-№ 1(80).

6. Zhudro I.S. Mezhdunarodno-pravovoi rezhim Severnogo Ledovitogo okeana v usloviyakh globalizatsii. Veroyatnye riski i ugrozy natsional'noi bezopasnosti Rossiiskoi Federatsii v Arktike // Armiya i obshchestvo. - 2015.-№ 1.

7. Kulebyakin V. N. Pravovoi rezhim Arktiki. Mezhdunarodnoe morskoe pravo / Otv. red. I. P. Blishchenko. - M., 1988.

8. Vylegzhanin A. N. Utochnenie predelov yurisdiktsii Rossii v Arktike na osnove obshchego mezhdunarodnogo prava// Mezhdunarodnye sudy: aktual'nye problemy mezhdunarodnogo prava / mezhvuzovskii sbornik nauchnykh trudov. - Vyp. № 2(6). - Ekaterinburg, 2010.

9. Peshchurov I. S. Rezhim dna Severnogo Ledovitogo okeana soglasno mezhdunarodnomu obychnomu pravu // Moskovskii zhurnal mezhdunarodnogo prava. - 2014. - № 3(95) iyul'-sentyabr'.

10. Vylegzhanin A. N. 20 let «vremennogo primeneniya» Soglasheniya mezhdu SSSR i SShA o linii razgranicheniya morskikh prostranstv // Vestnik MGIMO-Universiteta. - 2010. - № 1 . 